\title{
Konsep Pendidikan Agama Pada Zaman Milenial
}

\author{
Dinil Abrar Sulthani ${ }^{1}$ \\ ${ }^{1}$ Universitas Islam Jakarta \\ 1dinil.leader@gmail.com
}

\begin{abstract}
This article was written to explain the concept of religious education in the millennial era. The young generations who are in the millennial era experience various life dilemmas. The potential of the younger generation must be directed in order to understand the substance of their responsibilities. This thought article aims to provide an overview of the importance of reminding each other and synergizing with the younger generation. The older generation took the role to leave the next generation strong, strong in science, religious understanding, and skills innovation. Thought writing is described using the literature method with a qualitative descriptive analysis approach. The results of the study show that 1) The younger generation has the opportunity to become superior individuals, 2) The younger generation can maintain the existence of religion in society, 3) The support of the older generation is very important in controlling the activities of the next generation. The conclusion is that there are three educational concepts that can be realized; 1) Learn more diligently, 2) Practice actualizing knowledge, and 3) Useful for many things.
\end{abstract}

Keywords: Millennial Era, Religious Education, Young Generation

\begin{abstract}
Abstrak
Tulisan ini dibuat untuk menjelaskan tentang konsep pendidikan agama pada zaman milenial. Generasi muda yang berada pada zaman milenial mengalami berbagai dilema hidup. Potensi generasi muda harus diarahkan agar bisa memahami substansi tanggung jawabnya. Tulisan pemikiran ini bertujuan untuk memberikan gambaran kepada masyarakat pentingnya saling mengingatkan dan bersinergi dengan generasi muda. Generasi tua mengambil peran untuk meninggalkan generasi penerusnya yang kuat, kuat dalam ilmu, pemahaman agama, dan inovasi keterampilan. Tulisan pemikiran dijabarkan menggunakan metode kualitatif dengan pendekatan studi kepustakaan. Hasil dari kajian menunjukkan bahwa generasi muda memiliki peluang untuk menjadi pribadi unggul, selanjutnya generasi muda bisa menjaga eksistensi beragama di masyarakat, dan dukungan generasi tua sangat penting dalam mengontrol aktivitas generasi penerusnya. Kesimpulan tulisan bahwa terdapat tiga konsep pendidikan yang dapat direalisasikan yaitu; belajar lebih tekun, berlatih mengaktualisasikan ilmu, dan bermanfaat bagi banyak hal.
\end{abstract}




\section{Kata Kunci: Generasi Muda, Pendidikan Agama, Zaman Milenial}

\section{Pendahuluan}

Kondisi zaman sekarang berbeda dari zaman sebelumnya. Zaman sekarang sering disebut zaman milenial. Tantangan zaman juga terus berkembang. Perkembangan zaman ini terkadang membawa dampak terhadap proses penerimaan konsep pendidikan agama bagi generasi muda. Dampak ini memiliki dua sisi, dari sisi positif dan sisi negatif. Jika ditelusuri lebih dalam, dampak ini sudah berbaur dengan generasi muda sekarang. Akselerasi pengetahuan generasi muda cukup cepat, namun terkadang syarat dengan stigma instan. Misal dampak negatif, konten-konten tidak baik akan mudah diakses oleh generasi muda.

Generasi muda saat ini lebih senang dengan kebiasaan nongkrong yang disertai dengan minuman keras, seperti arak, tuak dan sejenisnya. Selain itu, berkendara di jalanan ngebut-ngebutan dan perkelahian antar kelompok. Perilaku seperti ini merupakan sebuah fenomena yang mencerminkan karakter generasi muda tidak baik. Perilaku tersebut merupakan tindakan yang dapat digolongkan sebagai kenakalan remaja. $^{1}$

Begitu juga dengan dampak positif, generasi muda mudah menemukan materi pelajaran agama. Namun, terkadang materi agama itu dicari yang paling singkat dan tanpa berpikir panjang. Dua dampak ini menjadi ciri khas kondisi zaman milenial. Posisi pendidikan agama kadang menempati posisi terakhir. Dengan perkataan lain, pendidikan agama mulai kehilangan identitasnya dari pikiran generasi muda. Jika generasi muda meninggalkan agamanya maka akan menjadi petaka yang mengerikan. Penyebab utama kerusakan moral para remaja adalah masalah-masalah pengangguran, pergaulan bebas, kerapuhan kepribadian, dan mental yang tak mampu memikul tanggung jawab. ${ }^{2}$

Waktu terus berputar akan memberikan jawaban di kemudian hari. Bagaimana generasi akan datang tanpa pemahaman pendidikan agama. Sedangkan, pendidikan agama adalah bekal terbaik dalam menjalani kehidupan. Masa yang terus berganti, namun pendidikan agama tetap relevan sepanjang zaman. Pendidikan agama tidak akan hilang oleh waktu. Agama akan mampu menjadi pemberi solusi dari setiap masalah.

\footnotetext{
${ }^{1}$ Suparno and Dasim Budimansyah, "Peran Nilai-Nilai Religius Kerajaan Sintang Dalam Membina Karakter Generasi Muda,” Jurnal Pekan 1, no. 1 (2016): 25.

${ }^{2}$ Misbahul Wani, "Pemuda Dalam Al-Qur'an Dan As-Sunnah: Pemuda Islam Yang Berkualıtas Tidak Lepasdarı Pendidıkan Orang Tua Yang Totalıtas," AL-DZIKRA: Jurnal Studi Ilmu Al-Qur'an Dan AlHadits 13, no. 1 (2019): 74.
} 
Intisari pendidikan agama adalah memberikan konsep perubahan dan perbaikan bagi manusia. Oleh sebab itu, jika pendidikan agama dihilangkan maka substansi atau hakikat menjalani kehidupan juga akan hilang. Kadang generasi muda tidak menyadari hal tersebut.

Rasa ingin tahu yang tinggi terkadang tidak seimbang dengan pengetahuan agama. Karena generasi muda dengan kepribadian yang belum stabil, emosional, gemar meniru dan mencari-cari pengalaman baru, serta konflik jiwa yang dialaminya merupakan sasaran utama orang, organisasi atau bangsa tertentu untuk mengaburkan nilai-nilai moral yang akan dijadikan pegangan dalam menata masa depan mereka. ${ }^{3}$

Akhirnya, generasi muda mudah terjebak dalam perilaku tidak baik, dan kadang cenderung ingin meraih hasil dengan instan. Pikiran instan akan membawa pengaruh yang tidak baik. Efek ini akan menghilangkan makna proses dalam berbuat. Terkadang meraih kesuksesan itu harus melewati proses yang beragam. Artinya, meraih kesuksesan itu identik dengan keberagaman. Dengan kata lain, ada yang menjalani proses dengan cepat dan ada pula yang lama. Ada yang menjalani proses dengan lancar dan ada pula yang mengalami rintangan.

Proses kondisi tersebut yang harus dipahami generasi muda. Untuk itu, apapun jenis prosesnya, jarang ditemukan bahwa keberhasilan mudah diperoleh dengan instan. Kadang faktor keberuntungan dan kuasa tuhan menjadi pengecualian, dan perihal tersebut tidak ada yang bisa membantahnya. Anggapan generasi muda harus segera diluruskan. Walaupun kondisi zaman sekarang serba canggih, namun pendidikan agama tetap utama. Karena faktor dan kunci keberhasilan di dunia dan di akhirat adalah pendidikan agama. Generasi muda perlu meluangkan waktu untuk belajar agama. Memahami secara perlahan dan bertahap, ikuti proses dengan sungguh-sungguh. Setelah mendapatkan ilmu bisa diamalkan untuk sendiri juga berbagi dengan orang lain.

Tulisan ini mengangkat berbagai argumentasi tantangan generasi muda pada zaman milenial. Konsep kajian literatur ini bertujuan memberikan jawaban dan masukan atas fenomena zaman yang berkembang. Karena jika tidak diberikan masukan dan saran akan memberikan dampak yang tidak baik di masyarakat. Dengan kata lain, tulisan ini sebagai bahan kajian untuk mengantisipasi terjadinya masalah di masyarakat. Sebagai visi bersama, bahwa tatanan di masyarakat harus tetap dilestarikan, salah satunya dengan cara memaknai konsep pendidikan agama secara utuh.

\footnotetext{
${ }^{3}$ Muzakkir, "Generasi Muda Dan Tantangan Abad Modern Serta Tanggung Jawab Pembinaannya," Jurnal Al-Ta'dib 8, no. 2 (2015): 111.
} 
Dengan demikian, tantangan atau masalah yang terjadi pada zaman sekarang dapat diantisipasi sedini mungkin. Artinya, generasi muda telah dipersiapkan dengan bekal pengetahuan dan langkah strategis menjadi pribadi yang unggul. Harapan dari konsep kajian ini menjadi bahan referensi dan informasi bagi masyarakat, secara khusus generasi muda. Dengan demikian, kajian tentang generasi muda bisa tetap memberi manfaat kapan dan dimana saja selama mereka berpegang teguh dengan konsep pendidikan agama yang diyakininya.

\section{Metode Penelitian}

Tulisan ini menggunakan jenis penelitian kepustakaan. ${ }^{4}$ Data yang diperole berupa data kepustakaan yang relevan mengenai pendidikan agama Islam di Indonesia berkaitan dengan perkembangan generasi muda milenial saat ini yang kemudian dianalisis secara deskriptif dengan menggunakan pendekatan analisis isi. Analisis deskripsi akan disajikan dengan diskusi secara mendalam. Menganalisis masalah dengan pendekatan kualitatif. Pendekatan kualitatif berdasarkan pada kajian kepustakaan dan menggunakan referensi relevan dalam merumuskan konsep yang ditawarkan kepada generasi muda. Tulisan ini akan mengurai atau menjawab tentang tantangan generasi muda dalam menjalankan aktivitas bermasyarakat. Aktifitas yang dimaksud sebagai bentuk upaya diri dalam membentuk eksistensi sesuai ajaran konsep agama dan konsep aktifitas yang dapat diterapkan oleh generasi muda di zaman milenial.

\section{Fenomena dan Kondisi Zaman Sekarang}

Kondisi zaman sekarang harus diperhatikan dengan benar. Di antaranya pengaruh media sosial. Pada dasarnya media sosial mempunyai sifat netral. Posisi netral ini bisa mengarah pada yang baik dan bisa juga mengarah pada yang buruk. Jika generasi muda menggunakan media sosial untuk hal positif, seperti membuat status atau informasi motivasi, kisah positif, dan berbagi pengalaman. Maka akan memberikan pengaruh yang baik. Apalagi media sosial yang digunakan baik itu bisa diikuti banyak orang. Tentu akan memberikan pengaruh yang signifikan. Inilah posisi terbaik dari penggunaan media sosial.

\footnotetext{
${ }^{4}$ Suharsimi Arikunto, Prosedur Penelitian: Suatu Pendekatan Praktek (Jakarta: Rineka Cipta, 1998), 10-
} 11. 
Posisi kebalikannya adalah saat generasi muda menggunakan media sosial untuk hal negatif. Seperti membuat status yang berisi cacian, keluhan, dan candu main games. Tentu, kondisi tersebut akan merugikan bagi generasi muda secara perlahan. Zaman yang serba canggih ini bisa menjadi buah simalakama. Tidak berbaur dengannya maka akan tertinggal. Sedangkan jika berbaur dengannya akan berada pada situasi yang penuh tantangan. Masyarakat sekarang harus bisa membaca kondisi tersebut. Melihat dengan pemikiran yang jauh ke depan. Artinya, masyarakat harus memperhatikan generasi selanjutnya, jangan sampai meninggalkan generasi yang lemah.

Inilah yang harus menjadi fokus penyelesaian masalah generasi muda zaman milenial. Masyarakat harus menyadari dengan benar masalah yang dihadapi generasi muda berbeda dari sebelumnya. Maka tindakan penyelesaian masalah juga harus berbeda. Tantangan pada generasi muda lebih bervariasi, sehingga sebagian generasi muda untuk mengatasinya. Masyarakat harus ikut andil bersama generasi muda menyelesaikan permasalahan yang muncul. Perihal ini sejalan dengan tujuan pendidikan, yaitu menyiapkan masyarakat menjadi umat Islam yang bertanggung jawab dalam mengatasi berbagai macam problem kehidupan. ${ }^{5}$ Efek usaha bersama tersebut akan memberikan kemudahan dalam mengatasi setiap masalah. Saling mengingatkan dan memberikan edukasi secara terstruktur.

Selanjutnya, masyarakat hendaknya melaksanakan pemantauan (monitoring). Nilai pemantauan ini sangat berguna untuk dilaksanakan. Misal, ada generasi muda yang melakukan onar, tawuran, atau merokok di pinggir jalan. Maka masyarakat tidak segan untuk menegur dan mengingatkannya. Ini bagian dari upaya menjaga generasi muda agar terhindar dari perbuatan yang tercela. Jika masyarakat abai dengan kondisi tersebut, maka generasi muda tidak akan paham bahwa tindakannya tersebut salah. Sikap abai tersebut termasuk salah satu faktor merusak tatanan sosial di masyarakat karena sebagian anggota masyarakat terjebak hanya sibuk mengurus diri sendiri.

Sikap individu yang egois akan mengalahkan aspek sosialisasi. Aspek individu dan sosial adalah dua fungsi dasar yang melekat pada setiap manusia. Maka dari itu manusia harus dapat menyeimbangkannya untuk menjadi manusia mulia (insan kamil). Manusia adalah makhluk sosial yang mempunyai kecenderungan untuk berinteraksi antara sesamanya, kecenderungan tersebut diperkuat oleh kebutuhan masing-masing

\footnotetext{
5 Bulu' Bulu', "Pendidikan Agama Islam Dalam Membendung Pengaruh Ajaran Aluk Todolo Di Tana Toraja Sulawesi Selatan," Jurnal Pendidikan Agama Islam (Journal of Islamic Education Studies) 4, no. 2 (2016): 180, https://doi.org/10.15642/pai.2016.4.2.179-205.
} 
akan jasa pihak lain karena berbagai keterbatasan yang dimilikinya. ${ }^{6}$ Ikatan di masyarakat sangat kuat, dengan kata lain rasa solidaritas harus dibangun. Bukti solidaritas ini akan membentuk peradaban maju. Masyarakat akan menjadi cerdas sehingga mempunyai status masyarakat ilmiah.

Keadaan zaman milenial yang tidak diberikan solusi akan menimbulkan masalah beragam. Misalnya, dalam kekukuhan di keluarga. Kekukuhan keluarga menjadi terancam sehingga kedamaian akan sulit terwujud. Oleh karena itu, penting memerhatikan kekukuhan keluarga. Kekukuhan keluarga adalah kualitas relasi di dalam keluarga yang memberikan sumbangan bagi kesehatan emosi dan kesejahteraan (wellbeing) keluarga. ${ }^{7}$ Keluarga memiliki upaya untuk menciptakan suasana yang menghidupkan, mendorong kemajuan, membuat evaluasi bersama hal-hal yang sudah terjadi dan dilakukan untuk memberi arah yang lebih baik, memberi penjelasan kemanfaatan hidup yang sehat, memberikan perhatian, menyediakan fasilitas dan memberikan bantuan yang diperlukan. ${ }^{8}$

Sebagian generasi muda lebih senang menceritakan masalah kepada orang lain dari pada orang tuanya sendiri. Proses edukasi tidak berjalan dengan baik di keluarga. Masalah ini bisa terjadi karena terkadang orang tua abai dengan pertumbuhan dan perkembangan psikis anaknya. Orang tua sibuk tenggelam dengan rutinitas kerjanya dan menyerahkan pendidikan anak sepenuhnya ke sekolah. Anggapan tersebut mengakibatkan anak akan merasa kehilangan rasa kasih sayang di rumah. Sehingga anak lebih memilih mencari perhatian dari luar. Perhatian dari luar yang ia temukan akan menjadi sandaran hatinya dalam bertindak.

Orang tua dapat menjadi tempat yang tepat bagi anak-anak untuk mencurahkan perasaan dan isi hatinya. Membiasakan menjalin komunikasi yang akrab antara anak dan orang tua akan membentuk sebuah kepercayaan pada diri anak. ${ }^{9}$ Pada masanya orang tua akan menyadari bahwa tindakannya selama ini keliru. Akhirnya, orang tua akan merasa kehilangan waktu dan tidak mempunyai kuasa dalam mengarahkan

\footnotetext{
${ }^{6}$ Surya Afdal, "Pendidik Sebagai Konselor Dalam Perspektif Pendidikan Islam," Jurnal Kajian Dan Pengembangan Umat 1, no. 1 (2018): 85, https://doi.org/10.32505/ikhtibar.v5i2.556.

7 Sri Lestari, Psikologi Keluarga: Penanaman Nilai Dan Penanganan Konflik Dalam Keluarga (Yogyakarta: Kencana, 2012).

${ }^{8}$ Mahmud, "Membangun Karakter Anak Dalam Keluarga," Jurnal Kajian Dan Pengembangan Umat 1, no. 1 (n.d.): 120.

${ }^{9}$ Chairinniza Graha, Keberhasilan Anak Tergantung Orang Tua (Jakarta: PT.Elez Media Komputindo, 2007).
} 
anaknya. Awalnya orang tua yang abai kepada anaknya, selanjutnya situasi itu berubah sehingga anak yang mulai abai kepada orang tuanya.

Zaman terus berputar, kadang perlakuan buruk itu akan balik ke pada diri sendiri. Tindakan orang tua ini perlu mendapatkan arahan agar jangan sampai salah mendidik. Orang tua harus disadarkan dengan tanggung jawabnya bukan hanya melahirkan anak dan membesarkan, namun juga untuk mendidiknya. Tanggung jawab orang tua disebabkan oleh dua hal; Pertama, karena kodrat, yaitu orang tua ditakdirkan untuk menjadi orang tua anaknya, dan mereka bertanggung jawab mendidik anaknya. Kedua, karena kepentingan orang tua, yaitu orang tua berkepentingan terhadap kemajuan dan perkembangan anaknya, sukses anaknya adalah sukses mereka juga. ${ }^{10}$

Masa pertumbuhan anak harus diisi dengan kasih sayang orang tua. Karena ikatan batin orang tua dan anak itu harus selalu terhubung. Jika ikatan itu terputus maka akan terjadi sikap miss-komunikasi dan miskonsepsi dalam keluarga. Itu sebabnya, tidak sedikit dijumpai generasi muda, mereka bersikap baik di luar rumah, namun kasar dengan orang tuanya. Generasi muda mampu menghadirkan wajah senyum dan ramah, namun ketus dan abai akan nasihat orang tuanya. Akhirnya, terkadang orang tua hanya bisa melampiaskan emosinya. Luapan emosi ini terkadang ada yang temperamental dan ada pula yang melankolis.

Jika orang tua bersikap temperamental, maka akan selalu terdengar pertikaian adu argumentasi antara anak dengan orang tua. Pertikaian yang tidak berujung pada solusi yang mencerahkan. Energi orang tua habis dengan sikap marah yang tidak berujung manfaat. Begitu juga sebaliknya, jika orang tua memiliki sikap melankolis, maka akan selalu sedih dan menyesali kondisi anaknya yang tidak patuh. Kondisi penyesalan itu mengakibatkan batin menjadi rapuh dan membawa penyakit. Nilai nasihat dipandang tidak bermanfaat lagi. Semua instruksi dan perhatian tidak tersampaikan dengan tepat. Karena sebelum orang tua memberi nasihat, si anak sudah menutup hati dan telinganya. Intisari hidup berkeluarga dengan damai tidak akan terwujud karena yang ada dalam rumah tersebut hanya pertentangan batin dan pikiran.

Rumah yang fungsinya sebagai tempat pendidikan pertama berubah hanya menjadi tempat berteduh saja. Tidak ada nilai-nilai edukasi yang terbangun. Anak tidak segan membantah pendapat orang tuanya. Karena bagi anak orang tua hanya pandai dalam memberi instruksi namun lemah dalam bertindak. Artinya, tidak ada nilai

\footnotetext{
${ }^{10}$ Ismail Syakban, "Eksistensi Manusia Perspektif Pendidikan Islam," Jurnal Kajian Dan Pengembangan Umat 2, no. 1 (2019): 62.
} 
keteladanan yang ditampilkan orang tua pada anaknya. Luapan kejenuhan inilah yang selalu memenuhi hati generasi muda. Jenuh dengan kondisi yang dialaminya saat di rumah karena ia kehilangan sosok panutan untuk menjadi pribadi yang baik.

\section{Konsep Pendidikan Agama}

Konsep pendidikan agama dapat diartikan aturan atau isi ajaran agama yang tersusun dengan rapi. Isi ajaran agama ini dikemas dengan baik secara sistematis, terstruktur dan komprehensif. Pendidikan agama yang termuat dalam konsep atau formal belajar dapat diakses semua orang. Secara khusus, bagi para peserta didik di lembaga pendidikan. Peserta didik akan memiliki hasil belajar yang maksimal jika guru yang mengajar memiliki kompetensi profesional, sebaliknya peserta didik akan mendapatkan hasil belajar yang tidak memuaskan jika diajar oleh guru yang tidak profesional. ${ }^{11}$ Artinya, jika guru belum profesional akan berpengaruh kepada hasil belajar peserta didik.

Lembaga pendidikan, melalui guru yang profesional dan berdedikasi tinggi akan mampu mengarahkan peserta didik menjadi pribadi baik. Secara khusus, guru yang mengajarkan pendidikan agama dengan profesional akan menguatkan pemahaman peserta didik. Pemahaman agama menjadi bekal bagi peserta didik dalam menjalani aktifitas sehari-hari. Karena pada dasarnya peserta didik adalah generasi muda zaman milenial yang masih membutuhkan pendidikan. Substansi pendidikan adalah memanusiakan manusia, menempatkan kemanusiaan pada derajat tertinggi dengan memaksimalkan karya dan karsa. ${ }^{12}$ Melanjutkan pendidikan adalah utama, suatu ketentuan yang sudah mengikat baik secara sukarela atau terpaksa. Artinya, generasi muda dijamin haknya mendapatkan akses pendidikan di dalam sistem pemerintahan Indonesia.

Oleh sebab itu, generasi muda diwajibkan untuk mengikuti rutinitas belajar di lembaga pendidikan. Pada lembaga pendidikan inilah nilai pendidikan agama diajarkan. Melalui pelajaran pendidikan agama, generasi muda akan mendapatkan informasi tentang keberadaan Tuhan. Keberadaan yang hakiki, pemilik alam semesta yang maha Esa. Kesempatan belajar di sekolah harus dimanfaatkan generasi muda dengan baik.

\footnotetext{
11 Agus Salim, Ahmad Lahmi, and Aguswan Rasyid, "Kontribusi Kompetensi Profesionalisme Guru Terhadap Peningkatan Motivasi Belajar Pendidikan Agama Islam," Ruhama : Islamic Education Journal 3, no. 2 (2020): 3.

12 Mardan Umar and Feiby Ismail, Buku Ajar Pendidikan Agama Islam : Konsep Dasar Bagi Mahasiswa Perguruan Tinggi Umum (Jawa Tengah: CV. Pena Persada, 2020).
} 
Sebab di sekolah mereka mendapatkan banyak informasi pengetahuan agama dan nilai moral dalam berinteraksi dengan orang lain. Generasi muda boleh saja hidup gembira, namun substansi hidup jangan sampai lupa.

Masa muda memang menyenangkan sehingga mereka lupa dengan substansi ajaran agamanya. Agama bisa merupakan salah satu faktor pengendali terhadap tingkah laku atau sesuatu yang dapat menstabilkan tingkah laku dan bisa menerangkan mengapa dan untuk apa seseorang berada di dunia ini. ${ }^{13}$ Secara khusus, agama Islam memberikan aturan bahwa hidup di dunia ini adalah seperti tempat bercocok tanam. Artinya, bekerja dengan kualitas dan kuantitas lalu hasilnya dapat dirasakan di hari akhir kelak. Islam mengajarkan para pengikutnya untuk bekerja atau beramal. Islam tidak mengenal istilah hanya cukup memiliki ilmu saja sebab yang menjadi poin utama dalam agama Islam adalah orang bisa beramal baik yang berlandaskan iman.

Peluang beramal di dunia masih terbuka selama hayat masih di kandung badan. Artinya, generasi muda masih bisa memaksimalkan potensi dan kekuatannya untuk bekerja. Jangan terjebak dengan buaian angan dan malas. Sebab, sikap tersebut hanya berakhir pada penyesalan di kemudian hari. Potensi yang harus dikembangkan terutama aspek fisik, psikis, intelektual, kepribadian, dan sosial sesuai dengan tuntutan kehidupan, kemajuan ilmu dan budaya, perkembangan masyarakat serta harapan ajaran Islam itu sendiri, terutama dalam menjadikannya mampu menunaikan tugas sebagai khalifah dan insan yang mengabdi kepada Allah SWT. ${ }^{14}$

Konsep pendidikan Islam memperjelas perannya untuk mengembangkan potensi yang ada pada diri manusia, karena potensi yang diberikan Allah pada akhirnya akan dipertanggungjawabkan di hadapan Allah. ${ }^{15}$ Melakukan semua perbuatan sesuai syariat agama. Jalankan anjuran agama dengan benar, patuhi perintah tuhan dan menjauh dari yang terlarang. Pahami aturan hukum yang berlaku baik dari hukum agama dan juga hukum norma masyarakat. Nilai-nilai hukum itu akan menjadi peringatan terbaik dalam beraktifitas bersama dengan anggota masyarakat yang lain. Sebab, nilai itu mengikat kepada semua orang, bukan hanya untuk diri sendiri.

\footnotetext{
${ }^{13}$ Muchammad Ainul Yaqin, "Pedidikan Agama Islam Dan Penanggulangan Kenakalan Siswa (Studi Kasus MTs Hasanah Surabaya)," Jurnal Pendidikan Agama Islam (Journal of Islamic Education Studies) 4, no. 2 (2016): 298, https://doi.org/10.15642/pai.2016.4.2.293-314.

${ }^{14}$ Lukis Alam, "Kontestasi Kebijakan Pendidikan Islam Di Era Orde Baru Dan Reformasi," Ruhana: Islamic Education Journal 3, no. 2 (2020): 72.

${ }^{15}$ Muhammad Fathurrohman, Prinsip Dan Tahapan Pendidikan Islam (Yogyakarta: Garudhawaca, 2017).
} 
Beragama bukan untuk diri sendiri, tetapi juga untuk orang lain. Islam mengajarkan kepada pemeluknya bahwa beragama itu harus saling mengingatkan. Saling mengingatkan tentang kebenaran dan saling mengingatkan dengan kesabaran.

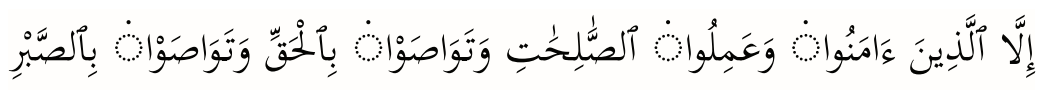

"Kecuali orang-orang yang beriman dan mengerjakan amal saleh dan nasihat menasihati supaya mentaati kebenaran dan nasihat menasihati supaya menetapi kesabaran"(Qs. Al-Ashr/103: 3).

Karena yang akan mendapatkan surga jangan hanya untuk diri sendiri, hendaknya juga mengajak orang beriman lainnya. Tiga hal perlu diperhatikan bagi umat Islam; Pertama, umat Islam tidak boleh menjadi umat yang bodoh, mereka harus mendapatkan pendidikan. Kedua, umat Islam harus menjalankan kewajibannya yang dengan itu ia mengetahui hak-hak yang harus ia miliki. Ketiga, umat Islam harus memiliki keterampilan dan skill sebagai sarana memperoleh hal yang berkenaan dengan hakhaknya. ${ }^{16}$

Agama Islam memberikan pemahaman yang jelas bagi pemeluknya. Pemahaman yang bersifat terbuka dan bebas. Artinya, manusia diberikan pilihan ingin memilih yang benar akan berakhir ke surga, dan jika memilih yang salah akan berakhir ke neraka. Lalu manusia bisa menentukan pilihannya, apakah menjadi muslim yang sejati atau hanya muslim simbolis. Untuk itulah generasi muda perlu memahami dengan baik konsepsi pendidikan agama. Agar mereka sadar dengan pilihannya dan bersedia bertanggung jawab dengan perbuatannya.

Sebagian masyarakat memahami pendidikan agama hanya sebagai aturan ajaran agama saja. Kalau pun lebih, itu hanya sebagai simbol atau status memiliki agama. Tentu perihal ini tidak baik untuk dipertahankan. Secara khusus, bagi generasi muda yang terkadang mereka masih berada pada masa transisi pemikiran dan kadang juga labil. Pemikiran yang berkembang di masyarakat cukup beragam. Artinya, definisi pendidikan agama banyak tafsirnya. Hal itu didasari pada sejauh mana tingkat pendidikan mereka dalam memahami konsep agama. Agama memang simbol, namun dalam pemaknaan lebih agama adalah suatu hal yang bersifat mendasar.

Kata mendasar tersebut berarti sebagai pedoman hidup atau formula cara hidup. Pedoman hidup ini menjadi tolok ukur bagi manusia dalam menjalankan aktifitasnya. Pendidikan agama menjadi penting untuk dibahas dalam situasi sekarang. Karena pembahasan agama harus diselaraskan dengan pemikiran masyarakat. Bahwa agama

${ }^{16}$ Syaflin Halim, "Pemikiran Hasan Al-Bana Tentang Pendidikan Islam," Ruhama : Islamic Education Journal 1, no. 2 (2019): 93. 
bukan barang antic yang harus ada di rumah ibadah saja. Tetapi agama bisa masuk dalam semua lini kehidupan manusia. Agama adalah ajaran yang berasal dari tuhan atau renungan manusia yang terkandung dalam kitab suci yang turun temurun diwariskan oleh suatu generasi ke generasi berikutnya dengan tujuan untuk memberi tuntunan dan pedoman hidup bagi manusia. ${ }^{17}$ Perbedaan waktu dan perubahan zaman tidak membatasi kehadiran agama. Artinya, agama mampu mempertahankan eksistensi dalam berbagai situasi dan kondisi apapun.

Hanya sebagian manusia saja yang mulai perlahan meninggalkan peran agama. Manusia ini menganggap agama adalah produk yang ketinggalan zaman dan cara hidup yang kaku. Bagi mereka, agama menjadi nomor dua bahkan tidak bernomor sama sekali. Pemahaman inilah yang dikhawatirkan memenuhi pemikiran generasi muda. Ingatan mereka akan tercurah pada hal yang keliru sehingga mereka meninggalkan norma agama dalam hal pertimbangan keputusannya. Ukuran kebenaran bagi mereka menjadi relatif dan subjektif. Lalu menyimpulkan dengan cara sederhana. Bahwa agama bukan menjadi tolok ukur dalam memiliki kepribadian masyarakat utama.

Oleh karena itu, hendaknya agama jangan hanya dipahami sebagai simbol belaka. Efek itu akan menjebak mereka pada sikap apatis, bahkan cenderung ateis. Kondisi seperti ini tentu tidak diinginkan sebab akan merugikan bagi dirinya bahkan generasi penerusnya. Nilai agama harus hadir memenuhi pikiran generasi muda. Mereka harus memahami intisari dalam beragama. Pendidikan agama akan mengajarkan banyak hal baru dan komprehensif dalam kehidupan. Intisari dalam beragama adalah berbuat. Dalam Islam, agama adalah beramal. Beramal yang menghasilkan sesuatu pekerjaan yang berkualitas.

Beramal itu menjadi terbaik jika diusahakan agar berkuantitas dan berkualitas. Agama Islam mampu memberikan jawaban terbaik dari setiap masalah dan tantangan yang dihadapi generasi muda. Pemaknaan Al-Qur'an dan hadis bisa menjadi alat penyelesaian masalah atau sumber solusi. Kajian dari ulama dan guru bisa menjadi referensi dalam berpikir dan bertindak. Dengan demikian, perlu menyisihkan sebagian waktu untuk mengenal agama dengan baik. Jika sudah kenal maka akan suka, suka dengan agama dan mulai mengimplementasikannya.

\footnotetext{
${ }^{17}$ Muh. Khoirul Rifa'i, "Internalisasi Nilai-Nilai Religius Berbasis Multikultural Dalam Membentuk Insan Kamil," Jurnal Pendidikan Agama Islam (Journal of Islamic Education Studies) 4, no. 1 (2016): 120, https://doi.org/10.15642/pai.2016.4.1.116-133.
} 
Konsep pendidikan agama selalu menawarkan perubahan ke arah yang baik. Perubahan yang mampu membentuk peradaban mulia. Perihal ini terbukti dari sejarah panjang manusia. Pada masa dahulu, sekarang, dan akan datang agama akan selalu eksis di masyarakat. Tentu eksistensi agama ini terbentuk karena kesadaran manusia untuk berpegang teguh dan mengamalkannya. Anggapan ini menunjukkan bahwa manusia masih membutuhkan agama, walaupun hanya sedikit. Dan juga dapat dipahami bersama, bahwa ada peran lain dari kekuatan yang Maha Kuat, Allah Swt.

Secara khusus agama Islam, Allah menjaga kemurnian Al-Qur'an melalui orangorang beriman yang hafal dan paham Al-Qur'an. Pemeliharaan Al-Qur'an ini sudah dijanjikan Allah. Artinya, agama Islam memiliki sumber rujukan hukum yang masih murni dan asli.

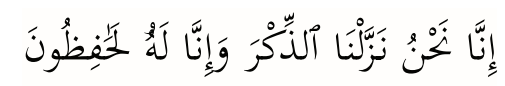

"Sesungguhnya Kami-lah yang menurunkan Al Quran, dan sesungguhnya Kami benar-benar memeliharanya." (Qs. Al-Hijr/15: 9)

Ajaran-ajaran yang termuat dalam agama Islam masih sama seperti awal di diturunkannya, hingga hari kiamat datang. Zaman yang berubah, waktu yang berganti tidak akan mengubah teks agama Islam. Hanya dalam pergerakan waktu, penafsiran dan pemaknaan Al-Qur'an bisa beragam dan berkembang. Perihal ini normal, sebab dalam memahami secara utuh makna Al-Qur'an tentu berbeda.

Manusia mempunyai tingkat penyerapan, kedalaman berpikir yang terbatas. Sedangkan, kandungan Al-Qur'an memiliki makna yang tinggi. Dalam kata lain, yang paham makna dan tafsir Al-Qur'an secara hakiki hanya Allah saja. Intisari dalam berislam adalah mengenal Allah dengan baik. Cara terbaik mengenal Allah adalah dengan membaca ayat tersurat (Al-Qur'an dan hadis) dan membaca ayat tersirat (makhluk dan alam beserta isinya). Semakin mengenal Allah dengan baik, maka akan semakin paham substansi hidup untuk beragama. Semakin sering mengulang pelajaran agama maka secara perlahan-lahan akan menemukan kebenaran hakiki dalam hidup.

Generasi muda sudah saatnya diarahkan untuk memprioritaskan pemahaman agama sejak dini. Efek dari pembiasaan ini akan membekas sampai di hari tua. Bahkan bisa diteruskan ke generasi selanjutnya. Pendidikan agama layak dan pantas untuk dipelajari selama manusia masih mendapatkan tantangan dan masalah. Nilai yang dapat diambil adalah bahwa manusia kepentingannya bukan hanya jasmani dan materi. Tetapi kebutuhan manusia berkaitan dengan ruhani atau spiritual. Maka, hanya konsep agama saja yang mampu memenuhi secara lengkap kebutuhan manusia. 
Indikasi dari kebutuhan manusia akan agama adalah kebuntuan dalam mencari ketenangan jiwa. Mereka bekerja, mereka menumpuk harta, namun hati selalu gelisah. Kondisi tersebut disebabkan mereka menafikan agama sebagai salah satu tujuan hidupnya. Agama memang menyediakan opsi kepada manusia. Opsi yang bisa dipilih secara utuh atau sebagian. Opsi pemilihan agama secara utuh adalah yang ditawarkan agama Islam. Lingkup serapan agama Islam luas sehingga memerlukan totalitas dalam beragama. Itu sebabnya, agama Islam mengajak manusia untuk menjadi insan kamil. Insan kamil adalah insan yang sempurna, totalitas dalam mengamalkan ajaran Islam dalam kehidupan sehari-hari. Untuk itu, pendidikan Islam dijadikan sarana yang kondusif bagi proses transformasi ilmu pengetahuan dan budaya Islam dari satu generasi ke generasi berikutnya. ${ }^{18}$

Kemajuan teknologi tidak bisa dibendung. Hari ini, esok, dan masa depan perkembangan informasi semakin beragam. Perkembangan itu tentu membawa tantangan baru bagi umat manusia. Penting bagi generasi muda untuk menyiapkan dan menyibukkan diri dengan tindakan yang tepat. Dan tindakan yang dilakukan itu berbanding lurus dengan konsisten berpegang teguh pada agama. Dengan agama, manusia khususnya generasi muda mendapatkan eksistensi dan substansi dalam menjalani kegiatan sehari-hari. Ada tiga aspek utama yang penting untuk dilakukan generasi muda agar eksis di masyarakat yaitu belajar, berlatih, dan bermanfaat.

\section{Belajar Lebih Tekun}

Generasi muda yang ingin memperkuat eksistensinya harus memiliki semangat dan tekun dalam belajar. Belajar mengenai berbagai hal yang berhubungan dirinya, agamanya, dan juga negaranya. Perilaku itu bisa terbentuk karena ada upaya untuk belajar. Pengalaman pernah melakukan kesalahan, maka ke depannya dapat bertindak benar. Sudah mengetahui perihal buruk, segera menghindar kepada yang baik. Pola pikiran seperti ini hanya bisa dibiasakan jika ada keinginan untuk belajar. Belajar adalah proses melihat, mengamati, memahami sesuatu. ${ }^{19}$ Zaman yang berubah bukan menjadi alasan malas belajar. Namun sebaliknya, jadikan itu sebagai motivasi bahwa jika malas belajar maka akan ketinggalan dalam kompetisi. Artinya, generasi muda di negara lain sudah melakukan banyak hal, namun di negara sendiri hanya jalan di tempat.

\footnotetext{
18 Bambang, "Manusia Dalam Al-Qur'an Dan Kaitannya Dengan Pendidikan," Jurnal Kajian Dan Pengembangan Umat 1, no. 1 (2018): 110.

19 Muhammad Fathurrohman, Belajar Dan Pembelajaran Modern: Konsep Dasar, Inovasi Dan Teori Pembelajaran (Yogyakarta: Garudhawaca, 2017).
} 
Malas belajar akan menyebabkan generasi muda menjadi manusia yang tertinggal. Tertinggal dalam ilmu pengetahuan, juga tertinggal dalam adab perilaku. Karena, belajar adalah upaya seseorang untuk dapat melangsungkan kehidupannya, semakin banyak belajar, semakin sempurna perilaku. ${ }^{20}$ Artinya, generasi muda perlu banyak belajar agar tidak buta terhadap peraturan, norma, dan nilai yang berlaku di masyarakat. Dengan kata lain, istilah tuna moral muncul yang berarti gagal paham dengan etika dalam bersikap dan berinteraksi dengan orang banyak. Oleh sebab itu, belajar menjadi kunci utama memperbaiki keadaan dan takdir sesorang. Lakukan kegiatan yang berhubungan dengan penambahan ilmu dan perbaikan akhlak diri. Kegiatan itu bisa berupa mengikuti kajian online atau offline, silaturahmi dengan karib, kerabat, dan teman sejawat. Banyak hal yang dapat dilakukan agar menjadi seorang pembelajar.

Belajar berarti mencari ilmu yang merupakan bagian penting dari proses pendidikan yang pada intinya adalah transfer ilmu dan nilai moral. ${ }^{21}$ Efek dari belajar ini sangat tinggi, selain memperkuat eksistensi diri di masyarakat. Belajar juga sebagai amalan baik yang terhitung ibadah di sisi Allah. Nilai yang termuat dalam ajaran Islam, belajar itu lebih utama dari beribadah. Tentu, pemaknaan belajar menjadi utama ini bukan mengabaikan perihal ibadah. Namun, yang menjadi poin penting adalah seorang berilmu yang beribadah dengan seorang beribadah saja tanpa ilmu tidaklah sama utamanya.

Intisari yang dapat diambil, belajar menjadikan generasi muda paham dengan apa yang dikerjakannya. Misal, saat berzakat dan berpuasa, selain paham ilmunya ia juga paham makna substansi dari pengalaman ibadah tersebut. Tentu, perihal ini akan memberikan pengaruh yang lebih kuat menjadikan diri menjadi muslim sejati. Agama dipelajarinya dengan sungguh-sungguh. Dikaji secara rutin makna teks dan konteksnya dalam kehidupan. Generasi muda yang sering mengulang kaji, belajar keras akan menerima hasil dari jerih payahnya. Belajar sesungguhnya merupakan proses mencapai ketenangan jiwa, mengaktualisasikan segala potensi, bakat, dan minat. ${ }^{22}$ Ladang amalnya ditanami dengan benih yang ikhlas dan kualitas. Pada saat memanen kelak

\footnotetext{
${ }^{20}$ Yulia Singgih D. Gunarsa, Asas -Asas Paikologi Keluarga Idaman (Jakarta: Gunung Mulia, 2002).

${ }^{21}$ Usman Usman, "Pendidikan Islam Dalam Perspektif Masyarakat Petani Madura," Jurnal Pendidikan Agama Islam (Journal of Islamic Education Studies) 6, no. 2 (2019): 254, https://doi.org/10.15642/jpai.2018.6.2.253-271.

${ }^{22}$ Rani Anggraeni Dewi, Menjadi Manusia Holistik (Jakarta: Mizan Publika, 2006).
} 
maka hati akan merasa puas. Kata dan sikap penyesalan akan jauh dari dirinya. Makna belajar inilah yang harus diraih oleh generasi muda zaman milenial.

\section{Berlatih Mengaktualisasikan İlmu}

Generasi muda yang telah belajar berbagai hal hendaknya jangan berhenti memendam pengetahuan. Sikap yang harus dilakukan adalah segera melaksanakan ilmu yang telah dipelajari. Proses yang harus ditempuh bukan sebentar, tetapi panjang dan hingga akhir hayat. Oleh karena itu, generasi muda hendaknya selalu berlatih diri agar muncul suatu tindakan yang terbiasa secara otomatis. Kebiasaan yang ditinggalkan akan ada perasaan yang belum lengkap. Ada suatu hal yang kurang jika belum menunaikan suatu kebiasaan. Sebagai contoh, seseorang yang terbiasa salat lima waktu, jika belum melaksanakan salat maka akan terasa di hati ada yang kurang. Hati seseorang akan gundah, tidak tenang, karena ada kebutuhan yang belum terpenuhi.

Pendidikan agama memberikan pemahaman tentang salat, bahwa salat dikerjakan bukan sebagai membayar kewajiban, tetapi suatu kebutuhan. Makna suatu kebutuhan ini bisa diraih jika seseorang terbiasa untuk berlatih dan merutinkan salat. Karena jika masih menganggap salat sebagai kewajiban berarti ada ilmu pengetahuan yang perlu ditingkatkan. Bahasan ini memberi penekanan bahwa hendaknya umat Islam mulai menyadari agama sebagai kebutuhan. Agama tidak boleh dipandang sebatas kewajiban saja. Sebab, umat Islam yang baik tentu ingin berusaha meningkatkan kualitas iman dan takwanya.

Maka perihal yang harus dibenahi dari awal adalah mau berlatih dan merutinkan amalan-amalan Islam dalam kehidupan sehari-hari. Bukan karena tuntutan kewajiban, tetapi suatu kebutuhan diri. Dan tingkatan yang lebih baik lagi, seseorang beragama atau beramal saleh karena rasa syukur dan cinta kepada Allah. Barang siapa mempelajari ilmu untuk diamalkan, maka ilmu itu akan membuatnya bersikap tawadhu dan tunduk kepada Allah. ${ }^{23}$ Intisari dari kesadaran ini sangat penting, sebab jika tidak ada kesadaran diri maka kadang dalam beramal saleh itu dalam keadaan terpaksa. Karena sebagian orang menganggap beragama adalah beban, menambah beban dan kesibukan seseorang. Sehingga ia dalam beramal menjadi kurang maksimal, ingin cepat selesai, seolah seperti dalam permainan.

\footnotetext{
${ }^{23}$ Syaikh Husain Bin Audah Al-Awaisyah, Prioritas Ilmu \& Amal (Jakarta: Pustaka Imam Asy-Syafi'i, 2007).
} 
Faktor lupa juga kadang bisa terjadi, terlalu sibuk bekerja sehingga lupa beribadah. Perihal ini terjadi karena agama bukan menjadi prioritas dalam hidup. Sehingga pikiran dan perasaannya tidak mampu mengingatkan badan untuk beramal saleh. Efek kebutuhan itu sangat mendasar, karena ia akan mampu membentuk suatu konsep prioritas yang tertanam dalam pikiran dan hati. Saat agama ditempatkan pada prioritas utama maka seluruh sendi kehidupan akan diwarnai dengan nilai-nilai agama. Karena agama mampu memberikan pengaruh kepada sikap manusia untuk menjadi berakhlak mulia. Nilai inilah yang patut diusahakan para generasi muda. Tentu nilai tersebut tidak secara langsung didapat tanpa usaha sungguh-sungguh.

Usaha sungguh-sungguh dapat diartikan menyiapkan diri untuk berlatih secara terus-menerus. Ingatkan pada diri sendiri bahwa membiasakan suatu perbuatan itu tidak instan. Kata ‘tidak instan' ini memberikan konotasi kadang masih terjadi kekhilafan dan kesalahan dalam bersikap. Namun sikap yang ditanamkan bahwa jika terjadi kesalahan dalam bertindak maka harus segera kembali ke koridor utama. Anggap semua usaha itu proses dan wajar keliru sebab belum terbiasa. Ada pada masanya, sesuatu yang diharapkan ada pada diri manusia akan menjadi keterampilan penting suatu saat kelak.

Seperti berlatih naik sepeda. Awal terjatuh sesekali dua kali itu wajar dan normal. Dan pesan utama yang didapat, ternyata usaha mencoba terus dilakukan, akhirnya pada masanya akan mudah mengendarai sepeda bahkan profesional. Lama latihan itu terkadang yang membuat sebagian generasi muda cepat bosan dan menyerah meraih keinginan atau cita-citanya. Sebab, mereka terlena dengan pandangan hidup serba instan. Dengan demikian, pendidikan agama harus hadir pada diri generasi muda agar memahami dengan benar sesuatu yang penting dalam menjalani hidup ini.

\section{Bermanfaat bagi Banyak Hal}

Generasi muda hendaknya menjadikan diri bermanfaat dalam banyak hal. Dalam konsep pendidikan agama, sebaik-baik manusia adalah yang bermanfaat bagi sesama. Dengan perkataan lain, bermanfaat adalah suatu tahapan akhir dari proses belajar dan mendapatkan pengalaman. Intisari dari belajar itu adalah mengejawantahkan ilmu dalam diri dan di masyarakat. Sehingga ilmu sebagai hasil dari belajar dapat dirasakan manfaatnya oleh orang lain. Ilmu yang bermanfaat adalah ilmu yang diamalkan, dan dengan tujuan yang baik, dipergunakan untuk amar ma'ruf nahi munkar. ${ }^{24}$ Masyarakat

\footnotetext{
${ }^{24}$ Saifuddin Bachrun, Manakemen Muhasabah Diri (Bandung: Mizania, 2011).
} 
yang mendapatkan manfaat akan mampu meningkatkan kualitas hidupnya. Legalitas keilmuan dengan sendirinya akan terbentuk. Artinya, generasi muda akan mendapatkan pengakuan dari masyarakat sebagai manusia terbaik yang mampu memberikan pencerahan hidup di lingkungannya.

Legalitas tersebut bersifat relatif, sebab komposisi suatu masyarakat itu beragam. Namun setidaknya para orang tua di masyarakat harus mengapresiasi dan mendukung setiap program positif yang dikerjakan generasi muda. Efek dukungan penuh dari masyarakat akan mampu menambah semangat generasi muda untuk lebih berkreasi. Sekarang mereka mengerjakan sesuatu yang kecil, tetapi tidak menutup kemungkinan di kemudian hari ia akan mampu berkarya yang dapat memberikan pengaruh besar bagi persada. Oleh karena itu, sikap terbaik dari orang tua dan masyarakat adalah memberikan kesempatan pada generasi muda untuk tampil berkreasi.

Saat berusaha sertakan dengan niat untuk investasi masa depan. Investasi yang tidak sebatas hanya uang, namun yang jauh lebih utama dari itu adalah investasi potensi kreasi inovasi. Karena, potensi jauh lebih mahal dan berharga tinimbang uang. Investasi uang hanya sebagai alat tukar dan interaksi ekonomi. Namun, potensi dapat membentuk suatu peradaban madani, baik pada bidang ekonomi itu sendiri, juga pada bidang lain; pendidikan, sosial, budaya, dan lainnya. Potensi itu lebih banyak pada generasi muda, sebab mereka masih fresh dan kaya akan gagasan unik yang relevan dengan zamannya. Fungsi pendidikan dalam Islam, salah satunya untuk mengembangkan alat potensial dari manusia dengan optimal sehingga dapat difungsikan sebagai sarana bagi pemecahan masalah hidup dan kehidupan, pengembangan ilmu pengetahuan dan teknologi, serta budaya manusia, serta pengembangan sikap iman dan takwa kepada Allah SWT. ${ }^{25}$

Pada dasarnya generasi muda memiliki tanggung jawab yang berat. Hanya saja, bahasa ini jarang terdengar bagi generasi muda. Karena mereka terjebak dalam masa yang menyenangkan. Dengan kata lain, mereka belum banyak mendapatkan masalah seperti masalah yang dirasakan para orang tua. Informasi inilah yang hendaknya harus dibicarakan dan terbuka kepada generasi muda. Peringatkan mereka akan tantangan dan masalah hidup yang semakin beragam. Juga karena banyak harapan yang dititipkan ke pundaknya. Sudah menjadi pemahaman bersama, generasi muda adalah harapan orang tua, agama dan bangsa. Artinya, beban harapan ini harus disadari sejak dini.

\footnotetext{
${ }^{25}$ Rudi Ahmad Suryadi, Ilmu Pendidikan Islam (Yogyakarta: Deepublish, 2018).
} 
Pada konteks yang lain, agama dan bangsa juga membutuhkan keterampilan generasi muda. Sebab, yang mampu menghadapi tantangan dan peluang di masa depan adalah generasi muda sekarang. Keberlanjutan suatu bangsa juga ditentukan dari generasi mudanya. Zaman sekarang sangat menentukan pada keesokan harinya. Generasi muda yang hari ini belajar agama akan mampu mengajarkan agama untuk generasi selanjutnya. Artinya, ada upaya kesinambungan dan korelasi tentang suatu program.

Alokasi waktu generasi muda lebih banyak dibanding generasi tua. Sebab generasi tua sudah sibuk dengan rutinitas pekerjaan dan mencari nafkah hidup. Generasi muda masih berada pada masa belajar, berproses, dan bereksperimen. Sehingga daya tangkap dan gerak mereka jauh lebih unggul dibanding generasi tua. Untuk itu, libatkan generasi muda dengan program pembangunan, ajak mereka untuk bersinergi. Generasi tua memberikan kesempatan generasi muda mengerjakan suatu proyek gagasan di masyarakat. Maka dengan upaya sinergi yang baik antara keduanya, niscaya generasi muda akan menjadi sosok pemberi manfaat bagi orang banyak. Memberikan manfaat sangat penting dan bisa dengan berbagai program kegiatan. Manusia memberikan manfaat dengan berbagai macam cara, bagi yang mempunyai harta bisa dengan hartanya, dan atau bisa juga dengan ilmu dan tenaga yang dimilikinya. ${ }^{26}$

\section{Penutup}

Dari narasi panjang di atas dapat dipahami bahwa generasi muda memiliki peran strategis dalam zamannya, zaman yang progresif cepat. Kata 'progresif cepat' ini dapat diartikan sebagai zaman milenial. Zaman yang mensyaratkan masa yang berpihak pada generasi muda. Perihal ini dapat disadari bersama bahwa generasi muda menjadi tempat harapan bagi semua orang. Harapan yang menjadi beban berat bagi mereka. Oleh sebab itu, para generasi tua jangan hanya berpangku tangan dan mengabaikan perkembangan kepribadian generasi muda.

Konsep penyerahan tanggung jawab kepada generasi muda harus tetap dikontrol karena merea juga butuh bimbingan dalam menemukan jati dirinya. Secara khusus, pembimbingan terhadap pemahaman konsep agama. Generasi muda harus diperkenalkan dengan agama sejak dini. Tujuan pengenalan ini dimaksudkan agar mereka memahami dengan benar substansi dalam menjalani hidup. Dalam konsep

${ }^{26}$ Habib Syarief Muhammad Alaydrus, Agar Hidup Selalu Berkah; Meraih Ketentraman Hati Dengan Hiudp Penuh Berkah (Bandung: Mizania, 2009). 
pendidikan agama, substansi menjalani hidup adalah melaksanakan aktifitas sehari-hari sesuai norma agama yang dianut. Secara khusus, dalam ajaran Islam. Generasi muda harus bisa memahami substansi hidup, yaitu beramal saleh, berjuang agar hidup bahagia di dunia dan di akhirat.

Terdapat tiga konsep pendidikan agama yang harus dipegang generasi muda dalam zaman milenial ini. Pertama, belajar lebih tekun, yang mensyaratkan generasi muda adalah warga belajar yang merdeka mengakses pendidikan. Kedua, berlatih mengaktualisasikan ilmu yang diperoleh. Ilmu yang didapat jangan berhenti pada diri sendiri, tetapi juga bisa dibagikan kepada teman, dan dikembangkan lebih luas. Ketiga, bermanfaat bagi banyak hal. Tujuan utama dari konsep pertama dan konsep kedua adalah menjadi pribadi bermanfaat. Generasi muda akan bisa menolong dirinya sendiri, orang lain, agama, dan bangsanya. Mereka akan disenangi manusia dan diberkati Allah SWT.

\section{Daftar Rujukan}

Afdal, Surya. "Pendidik Sebagai Konselor Dalam Perspektif Pendidikan Islam.” Jurnal Kajian Dan Pengembangan Umat 1, no. 1 (2018): 85. https://doi.org/10.32505/ikhtibar.v5i2.556.

Alam, Lukis. "Kontestasi Kebijakan Pendidikan Islam Di Era Orde Baru Dan Reformasi." Ruhana: Islamic Education Journal 3, no. 2 (2020): 72.

Al-Awaisyah, Syaikh Husain Bin Audah. Prioritas Ilmu \& Amal. Jakarta: Pustaka Imam Asy-Syafi'i, 2007.

Alaydrus, Habib Syarief Muhammad. Agar Hidup Selalu Berkah; Meraih Ketentraman Hati Dengan Hiudp Penuh Berkah. Bandung: Mizania, 2009.

Arikunto, Suharsimi. Prosedur Penelitian. Jakarta: Rineka Cipta, 2010.

Bachrun, Saifuddin. Manakemen Muhasabah Diri. Bandung: Mizania, 2011.

Bambang. "Manusia Dalam Al-Qur'an Dan Kaitannya Dengan Pendidikan.” Jurnal Kajian Dan Pengembangan Umat 1, no. 1 (2018): 110.

Bulu', Bulu'. "Pendidikan Agama Islam Dalam Membendung Pengaruh Ajaran Aluk Todolo Di Tana Toraja Sulawesi Selatan." Jurnal Pendidikan Agama Islam (Journal of Islamic Education Studies) 4, no. 2 (2016): 180. https://doi.org/10.15642/pai.2016.4.2.179-205.

Dewi, Rani Anggraeni. Menjadi Manusia Holistik. Jakarta: Mizan Publika, 2006.

Fathurrohman, Muhammad. Belajar Dan Pembelajaran Modern: Konsep Dasar, Inovasi Dan Teori Pembelajaran. Yogyakarta: Garudhawaca, 2017.

—. Prinsip Dan Tahapan Pendidikan Islam. Yogyakarta: Garudhawaca, 2017.

Graha, Chairinniza. Keberhasilan Anak Tergantung Orang Tua. Jakarta: PT.Elez Media Komputindo, 2007. 
Gunarsa, Yulia Singgih D. Asas -Asas Paikologi Keluarga Idaman. Jakarta: Gunung Mulia, 2002.

Halim, Syaflin. "Pemikiran Hasan Al-Bana Tentang Pendidikan Islam." Ruhama: Islamic Education Journal 1, no. 2 (2019): 93.

Lestari, Sri. Psikologi Keluarga: Penanaman Nilai Dan Penanganan Konflik Dalam Keluarga. Yogyakarta: Kencana, 2012.

Mahmud. "Membangun Karakter Anak Dalam Keluarga." Jurnal Kajian Dan Pengembangan Umat 1, no. 1 (n.d.): 120.

Muzakkir. "Generasi Muda Dan Tantangan Abad Modern Serta Tanggung Jawab Pembinaannya." Jurnal Al-Ta'dib 8, no. 2 (2015): 111.

Rifa'i, Muh. Khoirul. "Internalisasi Nilai-Nilai Religius Berbasis Multikultural Dalam Membentuk Insan Kamil.” Jurnal Pendidikan Agama Islam (Journal of Islamic $\begin{array}{llllll}\text { Education } & \text { Studies) } & 4, & \text { no. } & 1 & \text { (2016): }\end{array}$ https://doi.org/10.15642/pai.2016.4.1.116-133.

Salim, Agus, Ahmad Lahmi, and Aguswan Rasyid. "Kontribusi Kompetensi Profesionalisme Guru Terhadap Peningkatan Motivasi Belajar Pendidikan Agama Islam.” Ruhama : Islamic Education Journal 3, no. 2 (2020): 3.

Suparno, and Dasim Budimansyah. "Peran Nilai-Nilai Religius Kerajaan Sintang Dalam Membina Karakter Generasi Muda.” Jurnal Pekan 1, no. 1 (2016): 25.

Suryadi, Rudi Ahmad. Ilmu Pendidikan Islam. Yogyakarta: Deepublish, 2018.

Syakban, Ismail. "Eksistensi Manusia Perspektif Pendidikan Islam.” Jurnal Kajian Dan Pengembangan Umat 2, no. 1 (2019): 62.

Umar, Mardan, and Feiby Ismail. Buku Ajar Pendidikan Agama Islam : Konsep Dasar Bagi Mahasiswa Perguruan Tinggi Umum. Jawa Tengah: CV. Pena Persada, 2020.

Usman, Usman. "Pendidikan Islam Dalam Perspektif Masyarakat Petani Madura." Jurnal Pendidikan Agama Islam (Journal of Islamic Education Studies) 6, no. 2 (2019): 254. https://doi.org/10.15642/jpai.2018.6.2.253-271.

Wani, Misbahul. "Pemuda Dalam Al-Qur'an Dan As-Sunnah: Pemuda Islam Yang Berkualıtas Tidak Lepasdarı Pendidikan Orang Tua Yang Totalıtas." $A L$ DZIKRA: Jurnal Studi Ilmu Al-Qur'an Dan Al-Hadits 13, no. 1 (2019): 74.

Yaqin, Muchammad Ainul. "Pedidikan Agama Islam Dan Penanggulangan Kenakalan Siswa (Studi Kasus MTs Hasanah Surabaya).” Jurnal Pendidikan Agama Islam (Journal of Islamic Education Studies) 4, no. 2 (2016): 298. https://doi.org/10.15642/pai.2016.4.2.293-314. 